\title{
Embryo toxicity assay in the fish species Rhamdia quelen (Teleostei, Heptaridae) to assess water quality in the Upper Iguaçu basin (Parana, Brazil)
}

\author{
Izabella de Andrade Brito ${ }^{\text {a, b, * }}$, Juan Ramon Esquivel Garcia ${ }^{c}$, \\ Alexandre Barbosa Salaroli ${ }^{d}$, Rubens César Lopes Figueira e , César de Castro Martins ${ }^{\text {f }}$, \\ Alexandre Cordeiro Neto ${ }^{\mathrm{e}}$, Paloma Kachel Gusso-Choueri ${ }^{\mathrm{g}}$, Rodrigo Brasil Choueri ${ }^{\text {h }}$, \\ Sabrina Borges Lino Araujo ${ }^{\mathrm{b}, \mathrm{i}}$, Ciro Alberto de Oliveira Ribeiro ${ }^{\mathrm{a}, * *}$ \\ a Laboratório de Toxicologia Celular, Departamento de Biologia Celular, Universidade Federal do Paraná, Caixa Postal 19031, CEP 81531-970, Curitiba, PR, \\ Brazil \\ b Programa de Pós-Graduação em Ecologia e Conservação, Setor de Ciências Biológicas, Universidade Federal do Paraná, Caixa Postal 19031, CEP 81531-980, \\ Curitiba, Paraná, Brazil \\ ${ }^{\mathrm{c}}$ Estação de Piscicultura Panamá, Est. Geral Bom Retiro, CEP 88490-000, Paulo Lopes - SC, Brazil \\ d Instituto Oceanográfico da Universidade de São Paulo, Praça do Oceanográfico, 191, 05508-900, São Paulo, SP, Brazil \\ e Centro de Estudos do Mar, Universidade Federal do Paraná, Caixa Postal 61, 83255-976, Pontal do Paraná, PR, Brazil \\ ${ }^{\mathrm{f}}$ Departamento Acadêmico de Química e Biologia, Universidade Tecnológica Federal do Paraná, Curitiba, Paraná, Brazil \\ ${ }^{g}$ Núcleo de Estudos em Poluição e Ecotoxicologia Aquática, Universidade Estadual Paulista, São Vicente, São Paulo, Brazil \\ h Departamento de Ciencias do Mar, Universidade Federal de São Paulo, Santos, São Paulo, Brazil \\ i Departamento de Física, Universidade Federal do Paraná, 81531-990, Curitiba, Paraná, Brazil
}

\section{H I G H L I G H T S}

- The lethal andnon-lethal effects described suggest the presence of toxicity in water.

- Chemical analyses showed a high level of pollution in all studied sites along the River.

- Theoretical modelshowed that pollutants can reduce the fish population density including risk oflocal extinction.

- The present studysuggest an elevated risk to biota and for human populations.

\section{A R T I C L E I N F O}

\section{Article history:}

Available online 3 May 2018

Handling Editor: David Volz

\section{Keywords:}

Iguaçu river

Embryo toxicity

Ecological modeling

Rhamdia quelen

Water quality

\begin{abstract}
A B S T R A C T
The Iguaçu River is one of the largest and most important rivers in the Southern of Brazil. The Upper Iguaçu Basin is responsible for water supply (80\%) of the Metropolitan Region of Curitiba (MRC). After crossing a large urban region, the river is polluted by domestic and industrial sewage, but despite of that few ecotoxicological studies have been performed in order to evaluate the water quality from Iguaçu River. The aim of the present study was to investigate the risk of exposure of Iguaçu water to biota and also human population. In this terms, was utilized the survival effect and the morphological deformities in larval embryos of Rhamdia quelen, a native South America species. The results showed a high level of pollution in all studied sites along the Upper Iguaçu River including PAHs and toxic metals such as lead. The lethal and non-lethal effects described in earlier stages of development suggest an elevated risk to biota. This data was corroborated by the theoretical model, showing that the pollutants present in water from Iguaçu River may further reduce the fish population density including risk of local extinction. The present study reflect the needs to conduct in-depth research to evaluate the real impact of human activities on the endemic fish biota of Iguaçu River including the risk for human populations.
\end{abstract}

๑) 2018 Elsevier Ltd. All rights reserved.

\footnotetext{
* Corresponding author. Departamento de Biologia Celular, Setor de Ciências Biológicas, C.P. 19031 CEP: 81Curitiba - PR Brazil.

** Corresponding author.

E-mail addresses: izabella.brito@ufpr.br (I. de Andrade Brito), ciro@ufpr.br (C.A. de Oliveira Ribeiro).
} 


\section{Introduction}

According to the UNESCO (2015), the lack of water affects $40 \%$ of the world's population. In developing countries, the combination of demand and water quality degradation has resulted in a critical problem (Setti et al., 2001). The watercourses of rivers when traverse major cities in general loss the self-purification capacity leading to profound changes to the aquatic biota where the consequence may be the loss of biodiversity (Shepp and Cummins, 1997; Tundisi, 2011), also described by the Millennium Ecosystem Assessment (2005).

Forbes et al. (2001) reported that a major criticism of standard ecotoxicological tests is the difficulty in translating the experimental results or effects to populations. According to Beketov and Liess (2012), this is an important challenge in the field of aquatic toxicology where the causal relationships between exposure to contaminants and the ecological consequences in nature must be identified. The use of, many smaller-scale studies as microcosms and mesocosms have confirmed that many relevant factors are still necessary to understand the effects on large spatial scales.

Fish embryo testing in ecotoxicological studies has been largely utilized as an accepted method in different models. Studies have been performed using the zebrafish (Danio rerio), the Japanese medaka (Oryzias latipes), and the fathead minnow (Pimephales promelas). According to Embry et al. (2010), the life cycle stages of fish (through the embryo-larval stage) may represent a way to establish definitive testing strategies and will provide another option for the acute testing of juvenile or adult fish. In Germany, fish embryo tests are required for wastewater effluent testing as part of the guideline referred to as DIN 38415-6 (2001).

The Iguaçu River Basin is the largest in Paraná State (Vitule and Abilhoa, 2009), but according to IBGE (2008; 2010) is the second most polluted urban river of Brazil. The subbasin of the Upper Iguaçu River where the studied sites are concentrated is within a highly urbanized region with approximately 3.2 million inhabitants (IBGE, 2012). Approximately $60 \%$ of this population is currently served by a sewage system, and only $48 \%$ have access to both sewage collection and sewage treatment systems (Pegorini et al., 2003). Porto (2007) described the irregular urbanization of areas containing wetlands and fountainheads as another important factor in the decline of the water quality reserved for public supply. The Upper Iguaçu Basin is used for $78 \%$ of total water supply in Curitiba Metropolitan Region (CMR) (Abilhoa and Boscardin, 2004; SEMA, 2010). Additionally, an economic and ecological importance is attributed to Iguaçu River due to the endemism of about $75 \%$ of the total fish species (Zawadzki et al., 1999). Baumgartner et al. (2012) described 106 fish species in the Iguaçu basin and Siluriformes is the most abundant order. The current study considers the native Neotropical catfish Rhamdia quelen (Siluriformes) (Quoy and Gaimard, 1824), a well-known species largely utilized in fish farms, easy adapted to laboratory conditions presenting a high phylogenetic proximity to endemic Siluriformes species from Iguaçu River.

The aim of the present study was to investigate the water quality of the Iguaçu River and discuss the risk of exposure to the endemic native fish species and human populations. Thus, qualitative and quantitative analyses of most of the Persistent Organic Pollutants (POPs) and toxic metals were performed in five studied sites along the upper Iguaçu River affected by urban activities. Additionally, biomarkers were applied to the early stages of development of $R$. quelen in order to identify the risk of exposure experienced by the local biota and also by human populations. A theoretical model (Brito et al., 2017) was applied in order to assess information of the impacts on the species population density, related with the water quality and the toxic responses from the early stages of development of $R$. quelen species.

\section{Materials and methods}

\subsection{Studied area}

The Upper Iguaçu River basin is located at MRC Southern of Brazil and consists of approximately thirty main tributaries according to the Environmental Institute of Paraná (IAP, 2009) used for water human supply. In the present study were utilized five sites representing $40 \mathrm{~km}$ of the urban region surrounding the river. The criterion used to choose the studied sites was the most urbanized region and the main tributaries of the Iguaçu River (Fig. 1).

\subsection{Water sampling}

The water was sampling in all studied sites (December 2014) considering $30 \mathrm{~cm}$ depth in the water column and refrigerated for transport to the Cellular Toxicology Laboratory at the Federal University of Paraná. In laboratory the samples were immediately filtered through a paper filter ( $12 \mu \mathrm{m}$ in porosity) to remove suspended material and preserved at $4{ }^{\circ} \mathrm{C}$. Before experiments, the test solutions were prepared after 33\% and 50\% dilution in reconstituted water $\left(0.0065 \mathrm{~g} / \mathrm{L} \mathrm{CaCl}_{2}, 0.1335 \mathrm{~g} / \mathrm{L} \mathrm{MgSO}_{4}, 0.0004 \mathrm{~g} / \mathrm{L} \mathrm{KCl}\right.$ and $0.0105 \mathrm{~g} / \mathrm{L} \mathrm{NaHCO}_{3}$ ) (ASTM, 1993).

\subsection{Chemical analysis}

\subsubsection{Organic pollution extraction procedures}

Water samples (1 L each) from the studied sites were stored in sterile amber vials and filtered using filter paper with a porosity of $0.50 \mu \mathrm{m}$. The extraction procedures used were those described by Mater et al. (2004).

For solid phase extraction, cartridges the water samples were conditioned with $10 \mathrm{~mL}$ of hexane, $10 \mathrm{~mL}$ of dichloromethane, and $10 \mathrm{~mL}$ of methanol (high performance liquid chromatography). Next, $1000 \mathrm{~mL}$ were passed through C18 cartridges (Cleanet C18-S SPE, Agilent Technologies) at a speed of $6-8 \mathrm{~mL} \mathrm{~min}^{-1}$, dried under a nitrogen flow, and then eluted with $10 \mathrm{~mL}$ of hexane, $10 \mathrm{~mL}$ of a mixture of dichloromethane/hexane (1:1), $10 \mathrm{~mL}$ of a mixture of dichloromethane/ethyl acetate $(1: 1), 5 \mathrm{~mL}$ dichloromethane, and $5 \mathrm{~mL}$ of ethyl acetate. The resulting extract solution was placed in a rotary evaporator at $40^{\circ} \mathrm{C}$ and dissolved in $21 \mathrm{~mL}$ of acetonitrile, with a total pre-concentration of 500 times.

\subsubsection{Polycyclic aromatic hydrocarbon (PAH) determination}

After extraction, the organic extract was injected into a gas chromatograph (Agilent Technologies 7890) connected to a triple quadrupole mass detector (Agilent Technologies 7000) with a HP5MS capillary column $(30 \mathrm{~m} \times 0.25 \mathrm{~mm} \times 0: 25 \mu \mathrm{m})$. The initial oven temperature was $70^{\circ} \mathrm{C}$ for $4 \mathrm{~min}$, followed by an increase of $15^{\circ} \mathrm{C} \mathrm{min}{ }^{-1}$ to $150{ }^{\circ} \mathrm{C}$, plus a posterior increase of $3{ }^{\circ} \mathrm{C} \mathrm{min}{ }^{-1}$ to $225^{\circ} \mathrm{C}$. The temperature was then raised $5^{\circ} \mathrm{C} \min ^{-1}$ to $310^{\circ} \mathrm{C}$, and it remained at $310^{\circ} \mathrm{C}$ for $10 \mathrm{~min}$, for a total of $61.33 \mathrm{~min}$ of analysis. The injector temperature was set at $290^{\circ} \mathrm{C}$, and injection was performed in pulsed splitless mode, with $1 \mu \mathrm{L}$ injected. The source temperature of the detector was $250^{\circ} \mathrm{C}$.

For PAHs quantification, an external calibration curve was used with concentrations of $0.01,0.10,0.50,0.75,1.00,2.00,5.00$, and $10.00 \mu \mathrm{g} \mathrm{mL}^{-1}$, which were prepared from a solution of 16 priority PAHs (Supelco and Sigma-Aldrich Co.) according protocols from the US EPA.

\subsubsection{Determining polybrominated biphenyls (PBDEs), polychlorinated biphenyls (PCBs), and organochlorine pesticides (OCS)}

Quantities of PBDEs, PCBs, and OCs in water was determined 

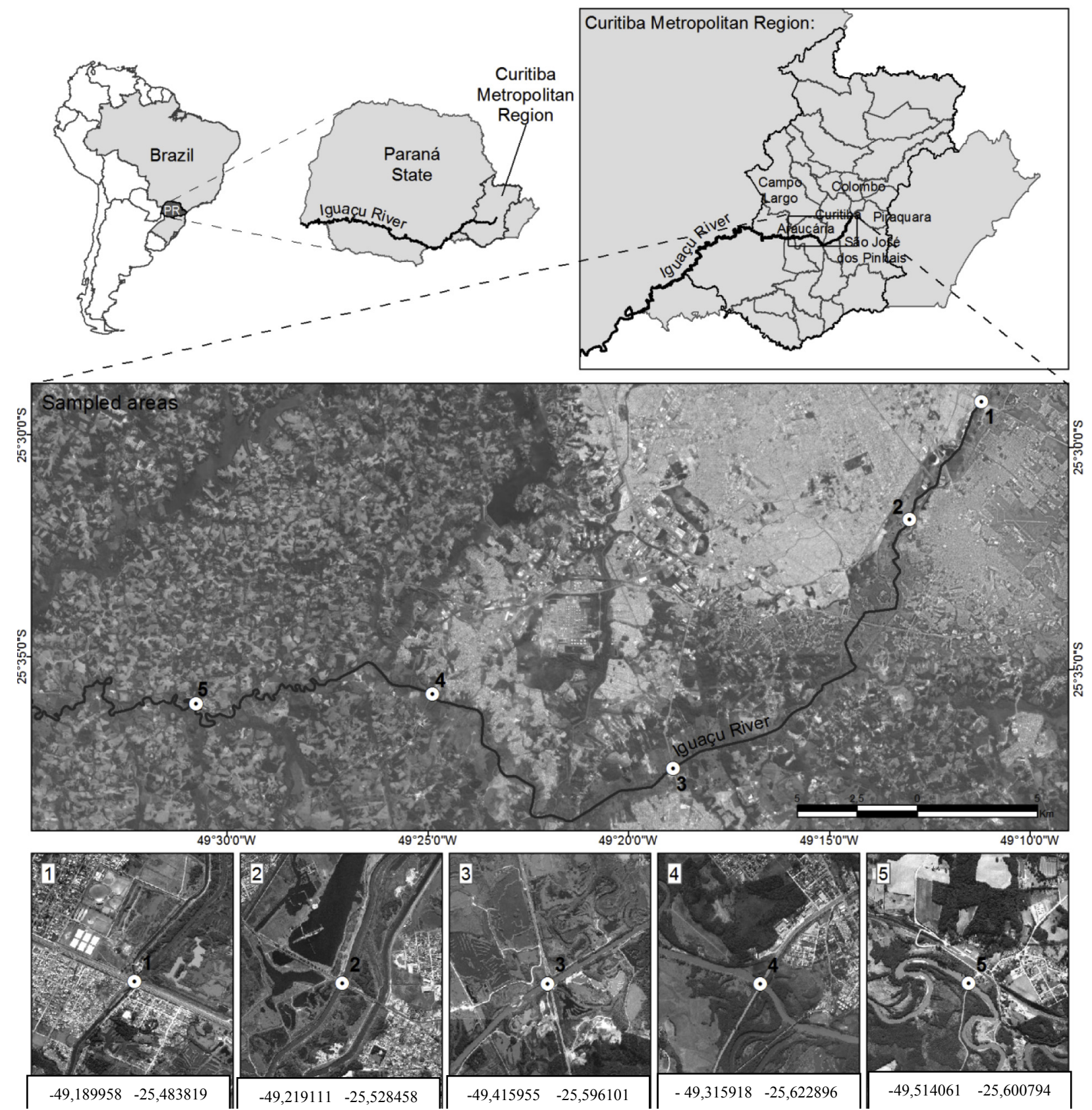

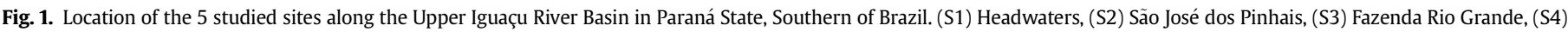

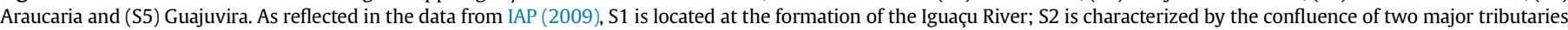

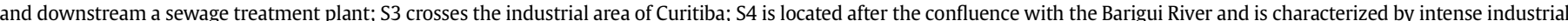
activities, including an oil refinery; and S5 is located $15 \mathrm{~km}$ downstream from the industrial region of Araucaria and receives all of the effluent from the greater Curitiba region.

using an Agilent 7890A gas chromatograph (Agilent Technologies, Palo Alto, CA, USA) connected to an Agilent mass spectrometer detector (Agilent 5975C inert MSD with Triple-Axis Detector). The gas chromatography column used was an HP-5 fused silica column (length $30 \mathrm{~m}$, ID $250 \mu \mathrm{m}$, film thickness $0.25 \mu \mathrm{m}$ ). The oven temperature was programmed to begin at $100{ }^{\circ} \mathrm{C}$ for $1 \mathrm{~min}$, increasing by $5^{\circ} \mathrm{C} \mathrm{min}^{-1}$ to $140^{\circ} \mathrm{C}$ (holding this temperature for $1 \mathrm{~min}$ ), then increasing by $1.5^{\circ} \mathrm{C} \mathrm{min}^{-1}$ to $250^{\circ} \mathrm{C}$ (holding for $1 \mathrm{~min}$ ), and finally increasing by $10^{\circ} \mathrm{C} \mathrm{min}^{-1}$ to $300^{\circ} \mathrm{C}$ (holding for $10 \mathrm{~min}$ ). The quantification of the analytes was based on a mixture of surrogate standards of PCB 103 (C-103 N) and PCB 198 (C-198 N) (both from AccuStandard, New Haven, CT, USA), which was added before sample extraction.
The organochlorine pollutants were identified through a comparison between the retention times based on the chromatographic peaks of the samples and those of external standard solutions using a known composition of 48 PCB congeners, 24 organochlorine pesticides, and 6 polybrominated biphenyls.

Data acquisition was performed in selected ion monitoring (SIM) mode, and the Agilent Enhanced G1701 CA ChemStation was used to perform the measurements. PBDEs, PCBs and OCs were identified by matching the retention times to ion mass fragments from a standard mixture at different concentrations $(1,5,10,20,80$, 100,150 , and 200-pg $\mu \mathrm{L}^{-1}$ ).

The quality assurance procedures included analyses of procedural blanks, surrogate recovery, and reference material (Wade and 
Cantillo, 1994). Procedural blanks were performed for each group of approximately nine samples using $20 \mathrm{~g}$ of sodium sulphate anhydride heated to $450{ }^{\circ} \mathrm{C}$ before extraction and analyzed in the same way as the samples were. The peaks found showed no external interference. The mean surrogate recoveries, which were based on the relationship with an internal standard (TCMX) added at the end of laboratory analyses, were found to be between 50 and $90 \%$ for PCB 103 and PCB 198.

\subsubsection{Chemical analysis of metals}

The water samples used for the chemical analysis of metals were kept in sterile, $1 \mathrm{~L}$ polyethylene bottles, fixed in nitric acid $\left(\mathrm{HNO}_{3}\right)$ $1: 1$, and kept under refrigeration at $4{ }^{\circ} \mathrm{C}$. The treatment used for to determine metal content was inductively coupled plasma-atomic emission spectrometry (ICP-OES), according to the protocol from the US EPA 6010C (EPA, 2007). The equipment used was an ES-710 Varian ICP-OES.

\subsection{Embryo-larval toxicity testing using $R$. quelen}

Fertilized eggs from $R$. quelen were obtained from a local fish farm (www.pisciculturapanama.com.br) and transported to the Cellular Toxicology Laboratory at the Federal University of Paraná. The embryos were maintained at a temperature of $24^{\circ} \mathrm{C}$, and only viable eggs were selected for study using a stereoscope microscopy Olympus ( $\times 0.67$ to 6.7 ).

For each tested solution from the study sites, ninety-six eggs $8 \mathrm{~h}$ post fertilization (hpf), a period which reflects the gastrula stage (Rodrigues-Galdino et al., 2010), were individually transferred into 96-well culture plates according to MacPhail et al. (2009). Each well-contained $200 \mu \mathrm{L}$ of tested solution prepared from each study sites samples (33\% and 50\% dilutions). A control group using only reconstituted water was assembled. The experiment was conducted in triplicate, with 288 embryos per tested solution and for each exposure time (24, 48, 72 and $96 \mathrm{hpf})$, thus totaling 2880 embryos per assay.

Every $24 \mathrm{~h}, 100 \mu \mathrm{L}$ (corresponding to $50 \%$ of the total volume) of the tested solutions from all of the 96 wells was changed to promote better levels of water oxygenation and ammonia removal. Hatching rates were determined $24 \mathrm{hpf}$. Embryo-larval survival was accepted at $96 \mathrm{hpf}$, and deformities were counted at 24, 48, 72, and $96 \mathrm{hpf}$. The embryo-larval were incubated at a constant temperature of $24^{\circ} \mathrm{C}$.

For hatching and survival rate analysis, the embryo-larval were counted individually in 96-well plates using a Leica ${ }^{\circledR} \mathrm{DM} / \mathrm{IL}$ inverted light microscope. For the morphological evaluation, embryolarval were collected and immersed in Karnovisky's fixative solution (glutaraldehyde $2.5 \%$, paraformaldehyde $2.5 \%$ in $0.1 \mathrm{M}$ sodium cacodylate buffer, $0.001 \mathrm{M} \mathrm{CaCl}_{2}, \mathrm{pH} 7.2$ ). After the fixative period (24 h), samples were washed with a $0.1 \mathrm{M}$ sodium cacodylate buffer $(2 \mathrm{x}), 10 \mathrm{~min}$ each, and then stored in 1 -mL plastic Eppendorf ${ }^{\mathbb{B}}$ vials at $4{ }^{\circ} \mathrm{C}$ until analysis. In order to determine toxic effects such as morphological alterations, damages, or deformities, the embryolarval were carefully transferred to microbiology well plates and photographed using a Sony ${ }^{\circledR}$ Cyber-Shot camera in an Olympus ${ }^{\circledR}$ light microscope. The deformities were classified into four categories according to Powers et al. (2011): (1) spine deformities (kink in tail, kyphosis or lordosis; (2) fin deformities (stunted or damaged); (3) facial/cranial deformities (oral deformities, eye swelling or absence of eyes); and (4) deformities of the thorax (cardiac edema, distension or body atrophy).

The experiments were certified by the Committee for the Ethics for Animal Experiments from the Biological Sciences Department of the Federal University of Parana (CEUA/BIO) in agreement with the Brazilian Guidelines for the Care and Use of Animals for Scientific and Teaching Purposes established by the Brazilian National Council for Control of Animal Experimentation (CONCEA), also within the international guidelines for animal experimentation.

\subsection{Statistical analyses}

Survival rates and deformities were analyzed using two-way ANOVA after confirmation of normality. Kruskal-Wallis tests were used to analyze the differences between the control and each of the samples. In addition, one-way ANOVA was performed to verify differences among the five sampled areas in terms of the values the chemical concentrations obtained. Statistical tests were performed in Prism 5.0 software (GraphPad, San Diego, EUA) assuming a value of $\mathrm{p}<0.05$ for statistical significance.

\subsubsection{Principal component analysis (PCA)}

The integration method sought to highlight associations among the variables measured in this study (both toxicity and contaminant levels) in water samples from Iguaçu River study sites that were diluted at two different concentrations (33\% and 50\%). Associations among the variables that indicate exposure (levels of metals and PAHs) and effects (mortality and spine, cranial and thorax deformities) were assessed using factor analysis with principal component analysis as the extraction method (FA/PCA). The variables were autoscaled (standardized) in order to be treated with equal importance. The variables selected for interpretation were those associated with the factors with a loading $\geq 0.50$, a value that is more conservative than the loading cut-off recommended by Tabachnic and Fidell (1996). The relevance of the associations observed at each of the five sampling points (cases) was estimated by calculating the factor score from each case for the centroid of all cases for the original data. All of the statistical and multivariate analyses were performed using the Statistica software tool (Stat Soft, Inc. 2013; version 12). The differences between the survival curves of the control bioassay and each river water dilution (33\% and 50\%) were analyzed using the log-rank test (Mantel-Cox test) at a 5\% significance level. The concentrations of $\mathrm{Co}, \mathrm{Cr}, \mathrm{Ag}$ and of PCBs were not included in the PCA, because these substances were not detected in the samples from any of the study sites located in the upper Iguaçu River.

\subsection{Modeling data}

A theoretical model described by Brito et al. (2017) based on individual-based models (IBMs) was used to assess the relationship between exposure to toxicity in the early stages of $R$. quelen and the impacts on the population dynamics of the species. The model considers three phases: Phase (A) is the embryo-larval stage, which corresponds to the first $96 \mathrm{hpf}$ that is characterized by the presence of the yolk vesicle. The only selection pressure imposed here is a constant survival rate, $S^{A}$. The impact of the pollutants in this phase is modeled by reducing the value of $S^{A}$. Phase (B) is the juvenile phase, which is measured from the complete absorption of the yolk (96 hpf) to one year of age. In this phase, the individuals begin exogenous feeding and horizontal swimming movements, but they are not yet reproductive. Durant phase B individuals forage locally and compete for resource. The survival rate in this phase, $b$, is then density dependent and its maximum value, $b$, corresponds to the maximum survival rate in the absence of interspecific competition. The impact of pollutants in this phase was modeled by reducing $b$, which means that individual survival probability decreases regardless of the number of competitors. Phase (C) is the reproductive adult phase, which include individuals from 1 to 21 years old that reproduces annually. Adults may die from natural causes and survival individuals may reproduce according to its age. It is 
assumed a constant annual survival rate, $S^{C}$. As in the previous phases, the impact of the pollutants in this phase is modeled by reducing the value of $S^{C}$. Since it is not known the real pollutant effect on juvenile and adults, we suggest to investigate different impact intensities ranging from the maximum impact, where the survival rates are zero, to the minimum impact where the survival rates corresponds to the values without pollutants: $S^{A} \max =0.6$ (Ferreira et al., 2001), $b \max =0.8$ (Piaia and Baldisserotto, 2000), $S^{C} \max =0.65$ (Gubiani et al., 2012). In this study, was used the value of $S^{A} \max =0.63$, because it was the survival value of larvae kept in reconstituted water (experimental control). It is also allowed to investigate the scenario where it is supposed that the pollutants affect the three phases with the same intensity I: $S^{A}=\mathrm{I} \times 0.63, b=\mathrm{I}$ $\mathrm{x} 0.8$ and $S^{C}=\mathrm{I} \times 0.65$, where $\mathrm{I}=1$ means no perturbation of the pollutant and $\mathrm{I}=0$ maximal perturbation.

Here the model was parameterized with data from the lowest dilution (33\%) groups considering that individuals with deformities reduced the survival rate because they lost the ability to respond to environmental stressors. As proposed by the original study (Brito et al., 2017), for each parameter combination, was considered an initial population composed of 20 individuals and then computed the relative population density, which was define as the adult population size divided by the average population size in a nonperturbative scenario (without pollutants). Was investigated the scenario where: (i) the pollutants affect larvae and juveniles (computing all combinations when $0 \leq S^{A} \leq 0.63$ and $0 \leq b \leq 0.8$ ); (ii) the pollutants affect larvae and adults (computing all combination when $0 \leq S^{A} \leq 0.63$ and $0 \leq S^{C} \leq 0.65$ ); (iii) the pollutants affect the three phases with the same intensity (I), where I was is the ratio $\mathrm{I}=S^{A} / 0.63$ (consequently $b=\mathrm{I} \times 0.8$ and $S^{C}=\mathrm{I} \times 0.65$ ).

\section{Results}

The distribution of the 16 PAHs and the total concentrations of PAHs (from 2.03 to $5.10 \mu \mathrm{g} \mathrm{L}^{-1}$ ) among the studied sites presented a large variation (Table 1). Site 5 was found to have the lowest concentration of PAHs in water, while sites 3 and 4 presented the highest values of these compounds. Naphthalene was the compound that presented the highest concentration $\left(2.68 \mu \mathrm{g} \mathrm{L}^{-1}\right)$ at $\mathrm{S} 3$. Acenaphthylene, naphthalene, fluorene, and chrysene were found at all of the study sites, but benz $[a]$ anthracene was identified at S1, S2, S3, and S4. Anthracene and phenanthrene were found only at S4. In general, compounds that have a lower molecular weight, or a weight between 2 and 3 aromatic rings (acenaphthylene, naphthalene, and phenanthrene), were found at higher concentrations at all of the study sites. An exception was benz[a]anthracene that was also found in high concentrations.

The parameters provided by Resolution $n^{\circ} 357 / 2005$ of the Brazilian National Environment Council (CONAMA) were used for comparison purposes. This agency described the concentration limits for certain PAHs, such as chrysene and benz[a]anthracene, and in the current study, these PAHs were found at values above legal limits at all of the study sites $\left(>0.05 \mu \mathrm{g} \mathrm{L}^{-1}\right)$ (Table 1 ).

The PBDEs, PCBs, and OCs were found at values below the detection limit for analysis in water at all of the study sites. The analysis of metals ( $\mathrm{Cu}, \mathrm{Mn}, \mathrm{Zn}, \mathrm{Fe}, \mathrm{Co}, \mathrm{Cr}, \mathrm{Ag}, \mathrm{Cd}$, and $\mathrm{Pb}$ ) are shown in Table 1. Copper presented values higher than the legal limits established by Brazilian legislation at sites S4 and S5 while manganese and iron were also found above legal limits at all of the study sites. Zinc was found at higher values at S1 and lead was found at higher values at S4 and S5.

The hatching rate of $R$. quelen embryos ( $24 \mathrm{hpf}$ ) exposed to water from all of the Iguaçu River study sites was higher at both dilutions (33\% and 50\%) when compared to the literature and control group. The control presented the lowest hatching rate and also presented a statistically significant difference $(\mathrm{p}<0.05)$ at $50 \%$ dilution at S3 and S4 (Table 2).

The embryo-larval survival rate among specimens exposed to water from the Iguaçu River study sites decreased as exposure time increased at both dilutions. Mortality was found to be high at all of

Table 1

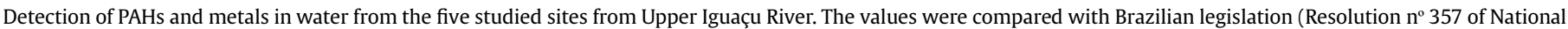
Council of Environment - CONAMA). The values are expressed in $\mu \mathrm{g} \mathrm{L}^{-1}$ and $\mathrm{mg} / \mathrm{L}$.

\begin{tabular}{|c|c|c|c|c|c|c|c|c|}
\hline PAHs $(\mu \mathrm{g} / \mathrm{L})$ & $\mathrm{S} 1$ & $\mathrm{~S} 2$ & S3 & S4 & S5 & LOD & LOQ & CONAMA $(\mu \mathrm{g} / \mathrm{L})$ \\
\hline Acenaphthene (Ace) & LOD* & LOD & LOD & LOD & LOD & 0.84 & 2.80 & - \\
\hline Acenaphthylene (Acy) & 0.87 & 0.74 & 0.74 & 0.77 & 0.65 & 0.17 & 0.57 & - \\
\hline Naphthalene (Nap) & 0.61 & 0.44 & 2.68 & 0.60 & 0.38 & 0.05 & 0.18 & - \\
\hline Fuorene (Flu) & 0.48 & 0.48 & 0.51 & 0.53 & 0.46 & 0.11 & 0.38 & - \\
\hline Phenanthrene (Phe) & LOQ & LOQ & LOQ & 0.89 & LOQ & 0.25 & 0.84 & - \\
\hline Anthracene (Ant) & LOQ & LOQ & LOQ & 1.15 & LOQ & 0.30 & 1.01 & - \\
\hline Fuoranthene (Fluo) & LOD & LOD & LOD & LOD & LOD & 0.81 & 2.71 & - \\
\hline Pyrene (Pyr) & LOD & LOD & LOD & LOD & LOD & 1.71 & 5.70 & - \\
\hline Chrysene (Chry) & 0.51 & 0.57 & 0.52 & 0.52 & 0.55 & 0.14 & 0.46 & 0.05 \\
\hline Benzo[a]anthracene (BaA) & 0.62 & 0.70 & 0.64 & 0.64 & LOQ & 0.16 & 0.53 & 0.05 \\
\hline Benzo[k]fluoranthene & LOD & LOD & LOD & LOD & LOD & 0.81 & 2.70 & 0.05 \\
\hline Benzo[b]fluorantene & LOQ & LOQ & LOQ & LOQ & LOQ & 0.55 & 1.82 & 0.05 \\
\hline Indene[1,2,3-cd]pyrene & LOD & LOQ & LOD & LOD & LOD & 0.66 & 2.19 & 0.05 \\
\hline Benzo[g,h,i] pyrene & LOD & LOD & LOD & LOD & LOD & 5.21 & 17.35 & 0.05 \\
\hline Dibenzo[a,h]anthracene (DahA) & LOD & LOD & LOD & LOD & LOD & 2.22 & 7.41 & 0.05 \\
\hline Benzo[a]pyrene (BaP) & LOD & LOD & LOD & LOD & LOD & 0.87 & 2.91 & 0.05 \\
\hline$\sum$ (PAHs) & 3.09 & 2.93 & 5.08 & 5.10 & 2.03 & - & - & - \\
\hline Metals (mg/L) & S1 & S2 & \multicolumn{2}{|c|}{ S3 } & S4 & \multicolumn{2}{|r|}{ S5 } & CONAMA $(\mathrm{mg} / \mathrm{L}) / \mathrm{L})$ \\
\hline Copper $(\mathrm{Cu})$ & 0.019019 & 0.013 & \multicolumn{2}{|c|}{0.011} & 0.009 & \multicolumn{2}{|r|}{0.007} & $0.009 \mathrm{mg} / \mathrm{L}$ \\
\hline Manganese (Mn) & 7.845 & 4.543 & \multicolumn{2}{|c|}{5.231} & 4.869 & \multicolumn{2}{|r|}{3.944} & $0.1 \mathrm{mg} / \mathrm{L}$ \\
\hline Zinc $(Z n)$ & 0.412 & 0.144 & \multicolumn{2}{|c|}{0.089} & 0.043 & \multicolumn{2}{|r|}{0.041} & $0.18 \mathrm{mg} / \mathrm{L}$ \\
\hline Iron $(\mathrm{Fe})$ & 1.700 & 1.410 & \multicolumn{2}{|c|}{1.447} & 1.327 & \multicolumn{2}{|r|}{1.059} & $0.3 \mathrm{mg} / \mathrm{L}$ \\
\hline Cobalt (Co) & $<\mathrm{MQL}^{\mathrm{a}}$ & $<\mathrm{MQL}$ & \multicolumn{2}{|c|}{$<\mathrm{MQL}$} & $<\mathrm{MQL}$ & \multicolumn{2}{|r|}{$<\mathrm{MQL}$} & $0.05 \mathrm{mg} / \mathrm{L}$ \\
\hline Chrome (Cr) & $<\mathrm{MQL}$ & $<\mathrm{MQL}$ & \multicolumn{2}{|c|}{$<\mathrm{MQL}$} & $<\mathrm{MQL}$ & \multicolumn{2}{|r|}{$<\mathrm{MQL}$} & $0.05 \mathrm{mg} / \mathrm{L}$ \\
\hline Silver (Ag) & $<\mathrm{MQL}$ & $<\mathrm{MQL}$ & \multicolumn{2}{|c|}{$<\mathrm{MQL}$} & $<\mathrm{MQL}$ & \multicolumn{2}{|r|}{$<\mathrm{MQL}$} & $0.01 \mathrm{mg} / \mathrm{L}$ \\
\hline Lead $(\mathrm{Pb})$ & $<\mathrm{MQL}$ & $<\mathrm{MQL}$ & \multicolumn{2}{|c|}{$<\mathrm{MQL}$} & 0.016 Co & \multicolumn{2}{|r|}{0.015} & $0.01 \mathrm{mg} / \mathrm{L}$ \\
\hline
\end{tabular}

${ }^{*} \mathrm{LOD}=$ Limit of detection; $\mathrm{LOQ}=$ Limit of quantification; $(-)$ Not present levels defined by law.

${ }^{a}$ Method quantification limit (MQL). The value can only be in the form of trace. below the detection limit with values in ppb or ppt. 
Table 2

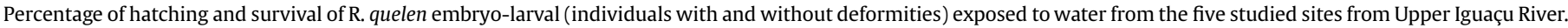

\begin{tabular}{|c|c|c|c|c|c|c|}
\hline \multicolumn{3}{|c|}{ Hatching (24 hpf) } & \multicolumn{4}{|l|}{ Survival (96 hpf) } \\
\hline Sites & Dilution $33 \%$ & Dilution $50 \%$ & Dilution 33\% (without deformities) & Dilution 33\% (with deformities) ${ }^{c}$ & Dilution $50 \%$ & Dilution 50\% (with deformities) \\
\hline 1 & 99 & 86 & 38 & 30 & 56 & 50 \\
\hline 2 & 98 & 98 & 55 & 48 & 49 & 36 \\
\hline 3 & 89 & 99 & 50 & 4 & 52 & 45 \\
\hline 4 & 95 & 99 & 49 & 45 & 56 & 53 \\
\hline 5 & 98 & 93 & 41 & 31 & 42 & 40 \\
\hline Control & $88^{\mathrm{a}}$ & 88 & $68^{\mathrm{b}}$ & 63 & 68 & 63 \\
\hline
\end{tabular}

a According to Andreatta (1979) in artificial cultivation systems, the hatching rate of eggs can approach $90 \%$.

b According to Ferreira et al. (2001) in artificial cultivation systems, the embryo-larval survival can approach $60 \%$.

${ }^{\text {c }}$ Dilution 33\% (with deformities) ${ }^{3}=S^{A}$.

the studied sites when compared to the control, which presented a $63 \%$ survival rate. The difference in the embryo-larval survival rate between dilutions and the control was significant after $96 \mathrm{hpf}$, indicating that exposure time is a significant factor that affects mortality rates among exposed individuals (Table 2). These differences were statistically significant between the control group and the 33\% dilution group from S1 and S5; they were also statistically significant between the control and the 50\% dilution group from S5.

The embryo-larval survival rate among specimens exposed to water from the Iguaçu River decreased as a factor of exposure time and dilution concentration. The same result was observed when the mortality rate was compared to that of the control group but the difference in the embryo-larval survival rate between dilutions and control groups was found after $96 \mathrm{hpf}$.

The survival rate was not different among the studied areas, and S1 and S4 presented the lowest survival rates at 33\% dilution (38\% and $41 \%$ respectively) while at $50 \%$ dilution, S5 presented the highest mortality rate.

The most common deformities were described as spinal, cranial, and thorax (Fig. 2). However, the major deformities were the spinal alterations, such as lordosis, kyphosis, and kinks in tails affecting the locomotion system. No significant differences in deformities
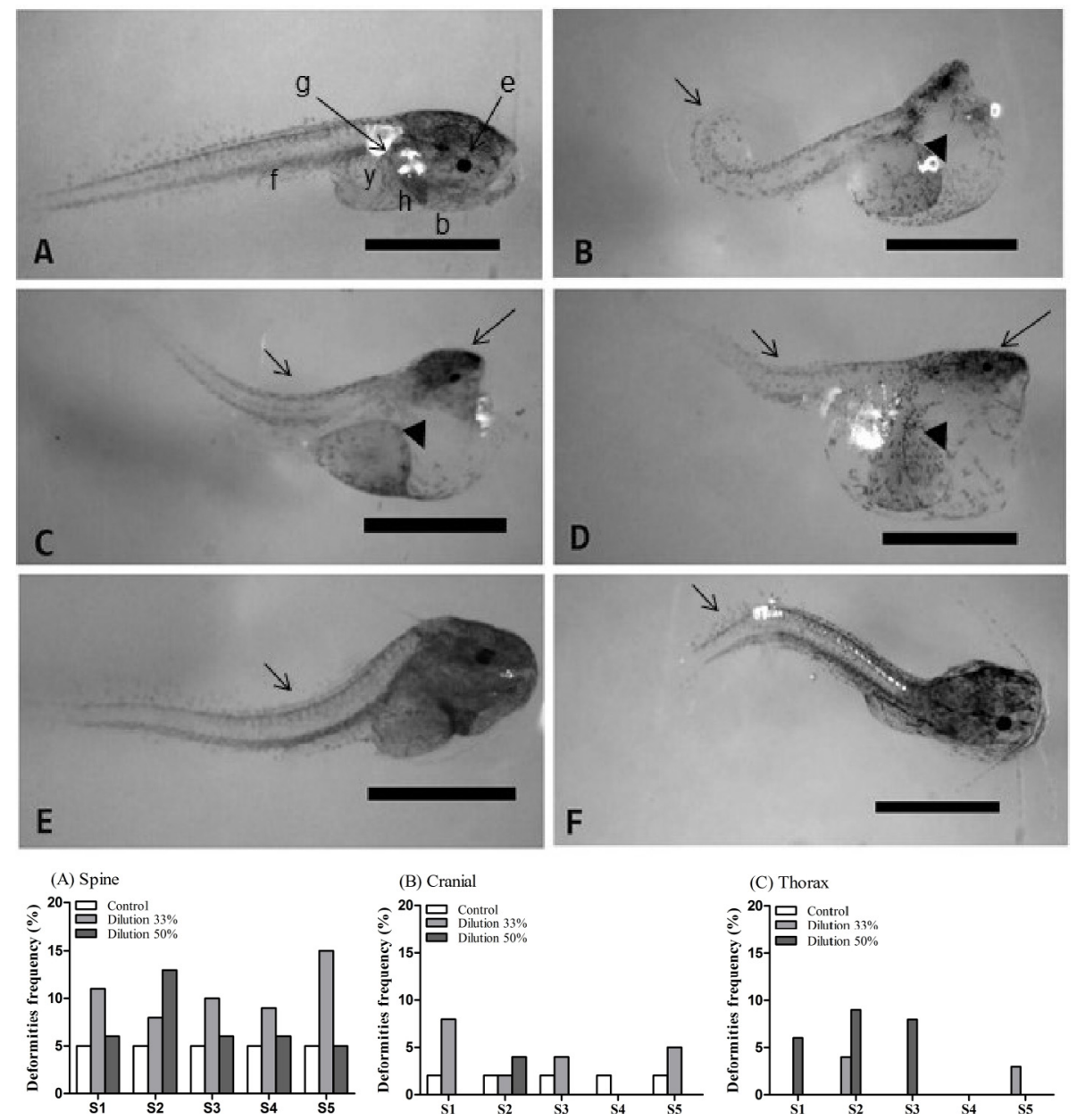

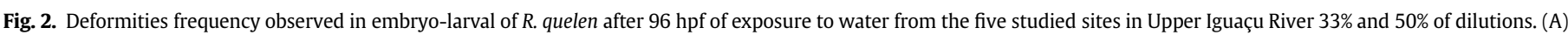

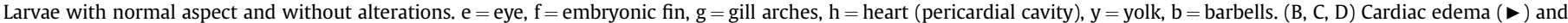

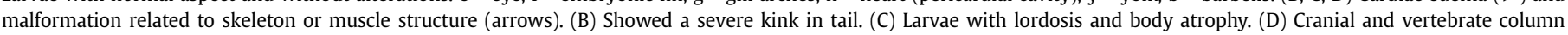
damages. (E) Lordosis. (F) Damage in the vertebrate column and body atrophy. Scale: $1.0 \mathrm{~mm}$. 
were observed among the studied sites $(\mathrm{p}<0.05)$. Nonetheless, individuals exposed to water from S5 (33\% dilution) presented the largest number of lesions. Among the thoracic deformities, cardiac edema was the most frequent, particularly when exposed to $50 \%$ dilution from S1, S2, and S3 (Fig. 2).

The results of the principal component analysis (PCA) presented 3 factors (F1, F2, and F3). The first (F1) explained 36.1\% of associations, while F2 explained $27.87 \%$ and F3 explained $25.89 \%$ (Table 3). According to the Kaiser criterion, only factors that explained more than $10 \%$ of the total variance were presented and discussed. The variables associated with a particular factor loading above 0.55 were considered relevant.

The concentration of metals $(\mathrm{Cu}, \mathrm{Fe}, \mathrm{Mg}, \mathrm{Zn})$ and the PAH acenaphthylene in the water were associated with F1 (positive loading values). The water from S1 and S3 were found to have higher scores

Table 3

Sorted rotated factor loadings of 20 variables on the three principal factors of the five studied sites from Upper Iguaçu River. Only variables with loadings > 0.55 (in bold text) were considered components of the factors.

\begin{tabular}{|c|c|c|c|c|}
\hline & \multirow[t]{2}{*}{ \% Variance } & \multirow{2}{*}{$\frac{\mathrm{F} 1}{36.10}$} & \multirow{2}{*}{$\frac{\mathrm{F} 2}{27.87}$} & \multirow{2}{*}{$\frac{\mathrm{F} 3}{25.89}$} \\
\hline & & & & \\
\hline 1 & $\mathrm{Cu}$ & 0.89 & 0.20 & 0.33 \\
\hline 2 & $\mathrm{Fe}$ & 0.97 & 0.22 & 0.09 \\
\hline 3 & $\mathrm{Mg}$ & 0.95 & -0.21 & 0.19 \\
\hline 4 & $\mathrm{~Pb}$ & -0.56 & -0.47 & -0.59 \\
\hline 5 & $\mathrm{Zn}$ & 0.83 & -0.05 & 0.46 \\
\hline 6 & Acenaphthylene & 0.95 & 0.02 & -0.08 \\
\hline 7 & Naphthalene & 0.26 & 0.04 & -0.14 \\
\hline 8 & Fluorene & 0.29 & 0.15 & -0.91 \\
\hline 9 & Phenanthrene & -0.06 & -0.10 & -0.94 \\
\hline 10 & Anthracene & -0.06 & -0.10 & -0.94 \\
\hline 11 & Chrysene & -0.71 & 0.51 & 0.43 \\
\hline 12 & Benz[a]anthracene & 0.37 & 0.89 & -0.26 \\
\hline 13 & Mortality 33\% & 0.25 & -0.86 & 0.37 \\
\hline 14 & Spine $33 \%$ & -0.40 & -0.79 & 0.45 \\
\hline 15 & Cranial 33\% & 0.45 & -0.47 & 0.76 \\
\hline 16 & Thorax 33\% & -0.68 & 0.46 & 0.51 \\
\hline 17 & Mortality 50\% & -0.84 & -0.09 & 0.53 \\
\hline 18 & Spine $50 \%$ & -0.08 & 0.95 & 0.20 \\
\hline 19 & Cranial 50\% & -0.19 & 0.91 & 0.26 \\
\hline 20 & Thorax 50\% & 0.47 & 0.70 & 0.40 \\
\hline
\end{tabular}

for this factor, so these variables can be understood to be at higher concentrations at these points. Lead and chrysene concentrations in the water were still associated with F1 but with negative values, as were high mortality at $50 \%$ dilution and thoracic deformities at $33 \%$ dilution. The strongest associations were at S5 and S2.

Associated with F2 (positive loading values) were the PAHs chrysene and benz[a]anthracene as were the spinal, cranial, and thoracic deformities ( $50 \%$ dilution); the highest score was observed at S2. F2 (negative loading values) also presented a relationship with mortality and spinal deformities at 33\% dilution; however, this relationship was not associated with pollutant concentrations. These associations were more frequently observed at S5 and S1.

F3 (positive value loadings) was associated with the embryolarval mortality rate (50\% dilution) and cranial and thoracic deformities (33\% dilution). Variables associated positively with this factor were most relevant at S1, S2, and S5. Concentrations of PAHs such as fluorene, phenanthrene, anthracene, and lead were associated F3 with negative values and were most relevant at S4. The estimated factor scores from all of the study sites are presented in Table 3, in which the prevalence of every component from each site is quantified and used to confirm the factor description.

Experimental data revealed the intense impact of pollutants on embryo-larval (phase $\mathrm{A}$ ) of $R$. quelen specimens exposed to water from the Upper Iguaçu River study sites. Thus, according to the theoretical model used, the impact on the early stages of development can interfere with the population density. Fig. 3 shows the evolution of this impact on the early life cycle stages of $R$. quelen over 200 years if the species' exposure to water from the Upper Iguaçu River study sites continues. In a non-disturbed scenario in the absence of pollutants, the density increases to maximum density, where it oscillates around a fixed value that represents the population average. When all of the Upper Iguaçu River study sites are considered, population density decreases relative to the control conditions.

When was considered the impact of exposure to Iguaçu River water only on phase A, a major decline in the number of individuals in embryo-larval stages can be observed (less than $50 \%$ survival in all areas), but an impact on population density does not occur (Fig. $4 ; b$ or $S^{C}$ are at maximum values). Even when was considered

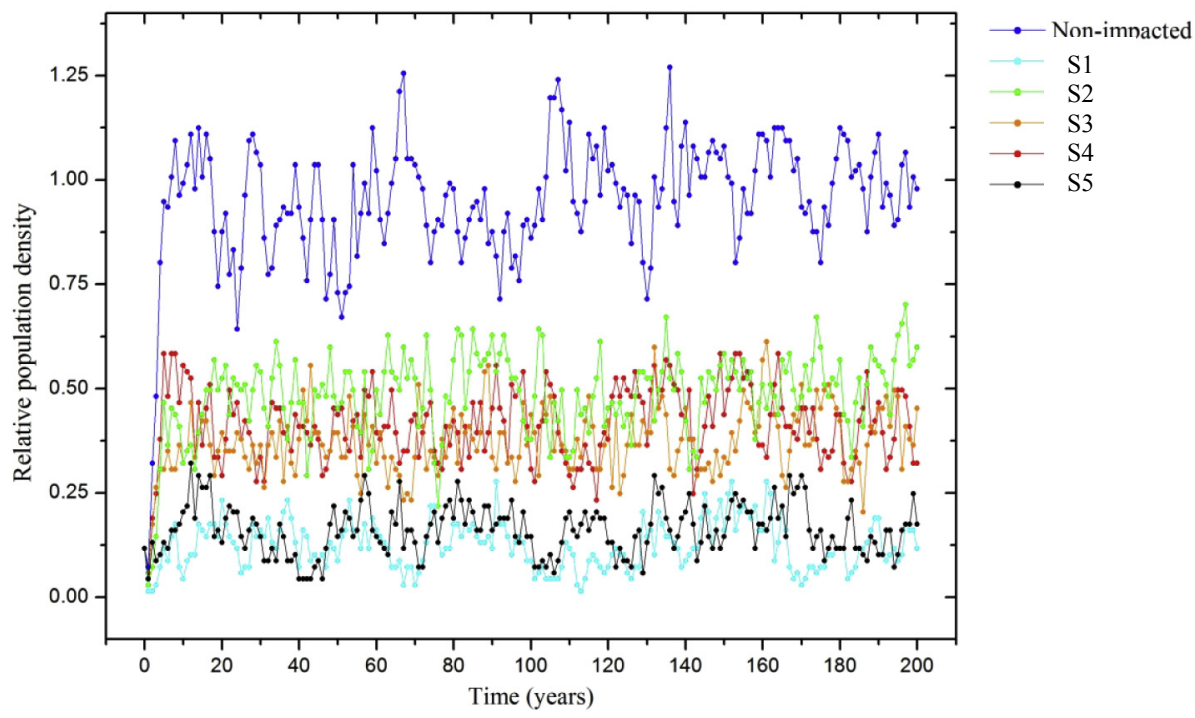

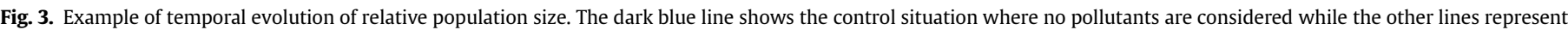

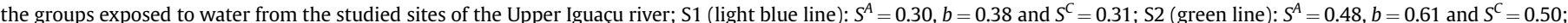

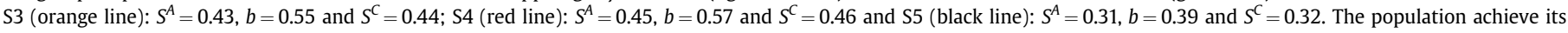
asymptotic behavior before 20 generations. 
(A)

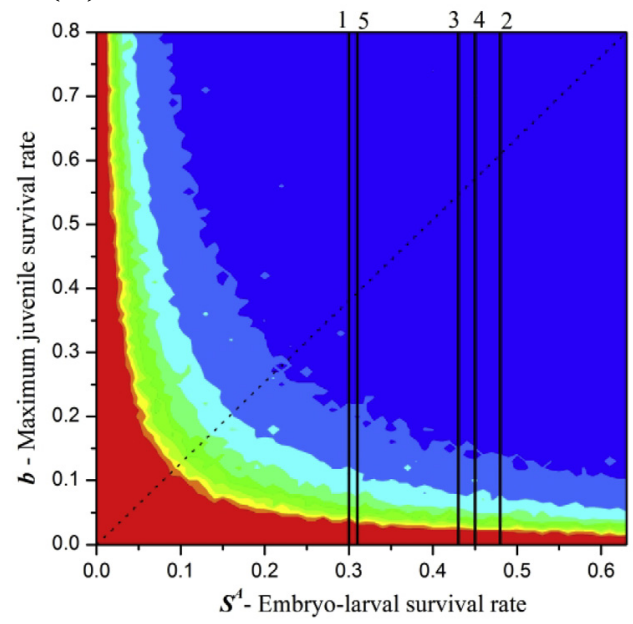

(B)

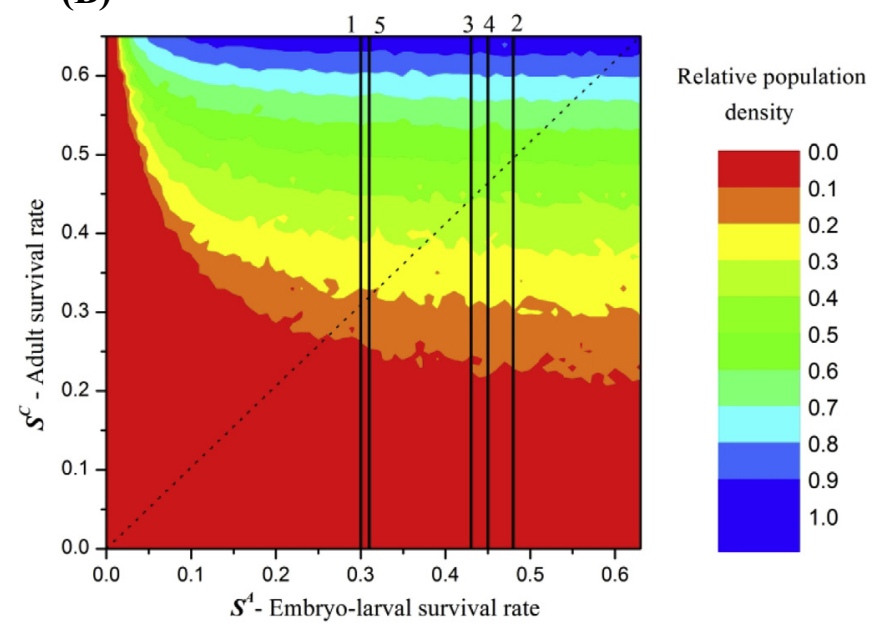

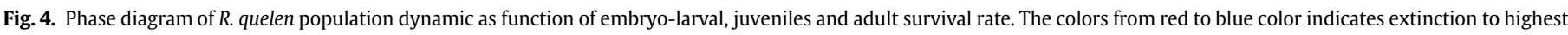

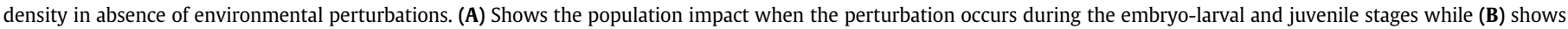

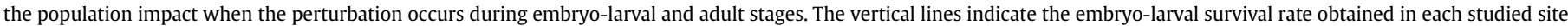

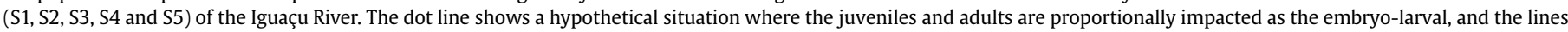
intersection correspond to the described for Fig. 4.

only individuals exposed to water from S1 and S5, which had the lowest survival rate $\left(S^{A}=0.30\right.$ and 0.31$)$, the population tends to reach maximum density in adulthood.

When was considered the impact that embryo-larval exposure has on the juvenile stage (phase B), the propagation of effects is low; the population is still quite resistant to disturbances (blue area in Fig. $4 \mathrm{~A}$ ). For most $S^{A}$ and $b$ combinations, population density is similar to population density in the absence of pollutants. Only when survival values for both stages are very low are a decline in population density and the risk of local extinction is observed.

The scenario represents the most important results of modeling: the impact of exposure to water from the Iguaçu River studied sites are also considered into adulthood (phase $\mathrm{C}$ ). The effect of pollutants on the embryo-larval stage is equivalent to the effect on adults. The exposure to water from the five study sites was found to have a strong effect on the size of the population (red area of Fig. 4B). S2 presented the highest embryo-larval survival rate; but population density remained close to $30 \%$ (intersection lines), a result which indicates that the impact propagates strongly when the adults stage is considered.

However, when we consider the pollutants affect the three phases with the same intensity (I), any reduction in the probability of survival reduces the population size (Fig. 3), where, in S1 the impact is $\mathrm{I}=0.48\left(S^{A}=0.30, b=0.38\right.$ and $\left.S^{C}=0.31\right)$; in $\mathrm{S} 2$ is $\mathrm{I}=0.76$ $\left(S^{A}=0.48, b=0.61\right.$ and $\left.S^{C}=0.50\right)$; in $S 3$ is $I=0.68 \quad\left(S^{A}=0.43\right.$, $b=0.55$ and $\left.S^{C}=0.44\right)$; in $S 4$ is $\mathrm{I}=0.70\left(S^{A}=0.45, b=0.57\right.$ and $\left.S^{C}=0.46\right)$ and in $S 5$ is $\mathrm{I}=0.49\left(S^{A}=0.31, b=0.39\right.$ and $\left.S^{C}=0.32\right)$.

\section{Discussion}

The absence of a pollution gradient for the presence of contaminants within the studied area of the Iguaçu River is explained by multivariate sources, but the presence of toxic metals and some organic pollutants in the water confirms the impact of urban and industrial activities on the river and the occurrence of run-off pollution. All the study sites located in the Upper Iguaçu River are highly impacted mainly by industrial and urban sewage. S1 is impacted by urban sewage and by the largest sewage treatment plant in the region (the Atuba Sul WWTP), which releases approximately $1.120 \mathrm{~L} \mathrm{~s}^{-1}$ of treated effluent within the Iguaçu River (Franco, 2010). According to IAP (2009), this area are historically classified as highly polluted. The mortality rates observed among embryo-larval after their exposure to water from S1 at 33\% dilution corroborates this data. It is important to note, however, that the second-highest mortality rate was found among specimens exposed to water from S5, which was more significantly impacted by PAHs than by metals. This data reflects the high complexity of the impact of these chemicals on the river.

Total PAHs concentration in the water from the study sites confirms that there is a constant release of this class of pollutants into the water; the values found reflect the impact of urban activities on the decreased water quality of the Iguaçu River. The most highly represented compounds were those of the pyrogenic class, including as acenaphthylene, and naphthalene. According to Zhang et al. (2004), these PAHs can be generated by the pyrolysis of wood or by coal burning, but Blanchard et al. (2004) described that the hydrolysis of organic matter originating from municipal sewage after wastewater treatment contributes to the increased levels of low-weight PAHs. Studies by SUDERHSA (1997) and COMEC (1999) indicate the fact that raw sewage dumped into the Iguaçu River is a source of PAHs. This data is logical, given with the presence of the 27 WWTPs distributed along the Iguaçu River and its tributaries (SANEPAR, 2015). In addition, emissions from human activities, incineration by-products from industrial and municipal waste, oil spills and oil derivatives and, in particular, the combustion of biomass and fossil fuels (Baird and Cann, 2008), all strongly contribute to PAHs concentrations in water.

The PAHs with a high molecular weight, such as chrysene and benz $[a]$ anthracene, were also quite abundant and over legal limits established by Brazilian Legislation at all of the study sites except S5. According to Soclo et al. (2000), these compounds are most frequently associated with fossil fuel burning; a correlation, which would explain their occurrence at, sites with high automotive vehicle traffic. Benz $[a]$ anthracene represented $23-43 \%$ of the total amount of PAHs identified in the water from the Iguaçu River study sites. The occurrence of this compound is of great concern due to 
the known carcinogenic potential ascribed to the molecule (WHO, 1998). Additionally, the fact that the highest concentrations of PAHs were found in water from S3 and S4 reflects the negative participation of the two major industrial areas of greater Curitiba.

Guo et al. (2009) report that, once they are released in the water, most PAHs spread as diffuse pollution and are deposited in the sediment because of their hydrophobic characteristics. This behavior would explain the lower level of these compounds at S5. This data is corroborated by Leite et al. (2011) who reported that the PAHs were found to be more concentrated in the sediment of Iguaçu River and particularly in the city of Araucaria (S4), which has large oil refinery. Still, the ubiquity of PAHs in the samples studied indicates a wide distribution of these compounds in all environmental compartments. Their high persistence and the tendency toward PAH bioaccumulation (Neff, 1979) reflect the fact that these compounds are an important class of pollutants in the Iguaçu River and that the local biota and human population are therefore at risk of exposure. According to the United States government, PAHs require a set of regulations to protect people from the possible health effects, and laws have been established to limit people is eating, drinking, or breathing of PAHs (ATSDR, 1995).

The amounts of polybrominated biphenyls (PBDEs), polychlorinated biphenyls (PCBs), and organochlorine pesticides (OCs) were found in the current study at values below detection limits (0.5-0.1 $\left.\mu \mathrm{g} . \mathrm{L}^{-1}\right)$. A large number of these contaminants represent a class of persistent organic pollutants that are of global concern, and they remain in most environmental matrices (water, sediments, soil, and air) (Breivik et al., 2002), and also in sewage, even after treatment (Yao et al., 2014). The high lipophilicity of these compounds may explain the absence of their detection in the water matrix, where filtration could prevent the detection of molecules associated with organic matter or even with microbiota. Leite et al. (2011) described a similar situation, particularly around S2 and S4, though below the concentration effect threshold (TEC). Thus, we cannot rule out the possibility that low concentrations of these compounds increase the risk of exposure among the biota of the Iguaçu River, a possibility which would also explain some of the results of this study.

The metal concentration observed in the headwaters around S1 could be explained by the release of treated sewage into this location, which is particularly common in the Atuba River. This release into the Atuba River negatively affects the quality of the Iguaçu water. According to the IAP (2009), this area has historically presented sewage pollution, with high levels of toxic metals $(\mathrm{Pb}, \mathrm{Ni}$, and $\mathrm{Cr}$ ). S3 is close to an intense industrial area where only $68 \%$ of sewage is treated and where only $82 \%$ of households are served by a sewer system. This region of the river is also impacted by pollutants from an inactivate landfill and from the leachate of an old treatment plant. The detection of lead and other metals in water from S4 and S5 is explained by the proximity of a high concentration of factories, including an oil refinery as well as the proximity of a very intense flow of automotive vehicles on the many highways nearby. This region was seriously affected by an oil spill in 2000, in which approximately four million liters of oil were spilled into the Iguaçu River along a $50 \mathrm{~km}$ extension (Katsumiti et al., 2013).

The higher hatching rates that occurred at both of the dilutions concentrations studied show that the chemical conditions of the Iguaçu River do not interfere with the initial stage of the species' development. However, the experimental design used does not allow for further discussion; only the eggs were exposed, which is an example of periodic exposure. A more complex study exposing the previous generation is necessary for an evaluation of the effects of Iguaçu water on egg development and, consequently, on the hatching rate. When the embryo-larval were exposed after hatching until 96 hpf, the effects of chemicals present in the water from
Iguaçu River were eminent. A significant mortality rate was observed as a dependent variable, a result which shows that the pollutants present in the river can decrease the survival rate of $R$. quelen embryo-larval. These conditions were observed at all of the study sites, a finding which suggests that the differences in chemical concentration among the sites did not significantly interfere with this parameter. A decreased survival rate among fishes in the embryo-larval stages has been reported by others and has been explained by the fishes' high sensibility to chemical pollutants (Kendall et al., 2001). According to the same authors, this kind of approach has been successfully adopted in the laboratory on a small scale in order to reproduce field conditions. Thus, the current study used chemical analysis and modeling as a promising tool for assessing the quality of the water from the Iguaçu River.

Skeleton deformities such as lordosis, scoliosis, and kinks in tails were the most frequently observed morphological effects on embryo-larval exposed to water from the Iguaçu River (S1) at 33\% dilution and on those from S2 at a higher dilution (50\%). This site in particular experiences a greater impacted from metals, but not from PAHs. In general, the sites with higher concentrations of metals in the water presented lower survive rates $96 \mathrm{hpf}$, and the concentrations exceeded those established by Brazilian law. The results therefore suggest that embryo-larval survival depends on toxic metal concentration in water, particularly when the metals are cooper, zinc, and manganese. This result is in accordance with the findings described by Adema-Hannes and Shenker (2008) when Coryphaena hippurus embryos were exposed to copper. Additionally, the same authors identified the development of edema and of skeletal and yolk sac deformities, while Debruyn et al. (2007) described an increase in the occurrence and severity of multiple skeletal deformities such as lordosis and scoliosis in Coregonus clupeaformis embryo-larval exposed to PAHs. Though most organic pollutants were found under detection limits in the current analysis, the effects of these pollutants and of others that were not investigated cannot be ruled out in the explanation of the deformities seen among embryo-larval of $R$. quelen.

The cranial abnormalities found in embryo-larval exposed to $30 \%$ diluted water from S1 and S3 are consistent with high levels of metals and of PAHs, respectively. This kind of parameter was reported by Debruyn et al. (2007) in larvae fish exposed to pesticides. Thorax injuries were more frequent in embryo-larval exposed to more highly diluted samples (50\%) from sites that experienced a greater impacted from metals ( $\mathrm{S} 1, \mathrm{~S} 2$, and $\mathrm{S} 3$ ), especially in the case of the cardiac edema. Similar results were described by Carls and Rice (1988) among larvae fish were exposed to PAHs. In the current study, S1, S2, and S3 presented the highest benz[a]anthracene concentrations, a finding which suggests that this kind of pollutant could be associated with this deformity.

The FA/PCA revealed relationships between the variables associated with the same axis (factor). When the variables from S1 were analyzed separately, a higher mortality rate, high concentrations of metals, and a relatively high amount of PAHs (3.09) were observed. These findings were corroborated by the FA/PCA and the factor scores for $\mathrm{S} 1$, since the analysis revealed that metals $\mathrm{Cu}, \mathrm{Fe}, \mathrm{Mg}$ and $\mathrm{Zn}$ ) and acenaphthylene in F1 were associated with toxicity responses in F2 (mortality and spinal deformities) and in F3 (mortality and cranial deformities). Although these variables were not associated with the same factor, these results suggest that the low quality of water at this site is correlated with mortality and with thorax deformities.

S2 revealed an important association between toxicity responses and some individual PAHs. F2 was the factor with the highest score, and the highest frequencies of deformities (spinal, cranial, and thoracic deformities) were associated with high levels of benz[a]anthracene. Though F1 and F3 presented lower scores, 
they were still found to have relevant toxicity endpoints - cranial deformities in F3, and thorax deformities and mortality in F1 - the latter of which were found to be associated with relatively high chrysene levels. S3 also had a positive score for F1 (which, as explained before, reflected metals and acenaphthylene to be associated with toxicity responses) and moderate toxicity responses associated with benz $[a]$ anthracene (as shown by the low positive score of F2). It is important to consider that, though naphthalene was not found to be associated with toxicity response in the FA/ PCA, it was found at the highest levels at S3.

S4 showed high of relevance of variables associated with F3 with negative loadings, including lead, fluorene, phenanthrene, and anthracene. F2 was also found to be moderately relevant (with a lower score) in terms of spinal deformities and mortality at $33 \%$ dilution at S4.

S5 presented negative scores for F1, which represents high frequencies of thorax deformities and mortality at 50\% dilution associated with lead and chrysene. The negative score for F2 and the positive score for $\mathrm{F} 3$ reinforce the toxicity at this site, since higher mortality (at 33\% dilution), deformities in the spine (both in F2), and cranial deformities (in F3) were all found to be associated. Mortality and frequency of the lesions are therefore thought to be associated with the pollutant concentration, a finding that suggests that the toxic responses observed in individuals may share a causeand-effect relationship with the pollutants measured. Thus, it can be concluded that heavy metals and organic pollutants generally result in early embryonic mortality and embryonic malformations. It is difficult to identify the substances responsible for physiological or behavioral disorders, though injuries can be linked to exposure to environmental stressors (Von Westernhagen et al., 1988), as well as to the temperature and physical-chemical parameters of the water (Prochazka, 2009).

In summary, FA/PCA results suggest that, at $\mathrm{S} 1$, metals $(\mathrm{Cu}, \mathrm{Fe}$, $\mathrm{Mg}$ and $\mathrm{Zn}$ ) and PAHs (acenaphthylene) can be found at higher levels and that, though they were not associated with the same factor, mortality and deformities (spine and cranial) were also relevant. At S2, several toxicity endpoints (mortality and deformities of the spine, cranium, and thorax) at both sample dilutions (33\% and 50\%) were relevant; these responses were associated with some PAHs (chrysene and benz[a]anthracene). This situation indicates that such compounds may have contributed to the toxicity levels observed. However, it is important to note that the concentrations of these compounds in the water varied only slightly among the sampling sites, a finding which indicates that other contaminants could also be responsible for this toxicity. S3 and S4 presented weak relationships between the measured contaminants and toxicity; at S3, metals presented moderate relevance and at S4, lead and some PAHs (fluorene, phenanthrene, and anthracene) were important variables. Finally, at S5, lead and chrysene were associated with mortality (50\% dilution) and, even when the samples were diluted at $33 \%$, these contaminants were associated with thorax deformities. At S5, mortality and spine deformity were also relevant.

Individual-based models (IBMs) have been applied with increasing frequency to environmental toxicology studies (Grimm, 1999), mainly due to their practical functionality in conservation studies. Thus, the modeling was applied to ecology in the present work to evaluate the impact of pollutants on embryo-larval catfish in order to make projections about future damages to populations.

The use of modeling tools is therefore scarce despite the support they offer to environmental management and conservation studies. The current modeling results are an additional and essential parameter for reiterating the evidence of the observed impacts of chemicals on the Iguaçu River and the consequent decrease in water quality. When the models were applied to the scenarios, pollutants were found to put limited pressure on phase A but more pressure on phase B. In other words, the effects of chemicals present in the Iguaçu River on embryo-larval and juvenile populations of $R$. quelen is not as evident in terms of potential extinction as when the effects on the population are considered. Another study conducted in 2014 (unpublished results) revealed that the exposure of embryo-larval to the same Iguaçu water without dilution resulted in a $100 \%$ mortality rate in all of the samples from the sites used in the current study. The early mortality rates observed in embryos clearly reflect the low quality of the water from the Iguaçu River. The current data, which is corroborated by other studies on Iguaçu River water quality (Machado et al., 2014a; b; Gallotta and Christensen, 2012), demonstrated that the presence of chemicals due to human activities potentially endangers the native fauna due to the negative effects on health, survival, and reproductive success.

When the scenario in which the pollutant pressure affects the juvenile phase (B) was analyzed, a higher mortality rate was observed than that of the juveniles in the absence of pollutants. However, it is thought that the population will be able to recover the balance over the years in this scenario. Meanwhile, when the propagation effect of pollutants on adult $R$. quelen specimens was analyzed, individual oscillations were found to be quite sensitive. When specimens were exposed to water from S2, a higher embryolarval survival rate was observed, though the population density was found to be below 50\%. This result differs from those of S3 and S4 - populations exposed to those pollution conditions were found to have a density below $40 \%$. At S1 and S5, population density fell below $10 \%$.

According to Lande (1993), smaller populations are more sensitive to stochastic events. This idea likely explains the extinction predicted in the models that used populations exposed to water from S1 and S5. Thus, both internal mechanisms (demographic stochasticity) or external mechanisms (environmental stochasticity) could be the cause (Pimm et al., 1988). Although stochasticity may indicate the probability of the size of a given population (Renshaw, 1991), the modeling allows us to discern between different stochastic processes, such as the persistence or extinction of a population. This finding is important, since individual variability may be crucial for the regulation and persistence of a studied population (Uchmanski, 1999). Additionally, this parameter can be used in the evaluation of future scenarios by measuring the risk of exposure and broadening the set of ecotoxicological tests in order to achieve a better understanding of the presence of chemicals in aquatic environments.

Sewage discharge regulation in Brazil follows Resolution 357/ 2005 by the Environment National Council (Brazil, 2005). However, as described by McKean (1980), many other substances that are present in sewage as a result of urban or even industrial activities are not covered under the current legislation. Water quality monitoring based only on physical and chemical parameters and some biological aspects results in an incomplete diagnosis and may obscure the real conditions and water quality (Lied and Rodrigues, 2011).

The Upper Iguaçu River was classified by Brazilian Legislation (Brazil, 2005) as source of water for human supply after adequate treatment and protection of the aquatic biota. So, the present study points to at least two problems: (I) it is urgent that a monitoring program be developed to evaluate the current risk of exposure experienced by the biota and the human populations along the Upper Iguaçu River through parameters other than those established to Brazilian legislation, and (II) the country needs to consider using other biological parameters in order to investigate water quality.

Many studies have reported that the current treatment is not satisfactory. Nieto (2000) described that $66.7 \%$ of the effluent from 
industrial activities still presents risk of exposure after treatment. The same situation was described by Knie and Lopes (2004) in a study on the treatment of leachate from the largest landfill in Curitiba, located downstream from S3, and also by and Hamada (2008) in a study on household and industrial waste. In general, these studies showed the inefficiency or only partial success of the sewage treatment methods that are currently in use in the region. In conclusion, the important findings of the current study highlight points that could be strategic for environmental management policies.

\section{Conclusions and future directions}

The five sampled areas of the upper Iguaçu River (S4 and S4 in particular) were found to have copper, manganese, zinc, iron, and lead concentrations above the legal limits established by Brazilian law. The water was also found to have high concentrations of PAHs - particularly acenaphthylene, naphthalene, fuorene, chrysene and benz[ $a$ ]anthracene - at all of the sites. This finding is indicative of contamination by both treated and untreated domestic sewage, industrial waste, and diffuse sources of pollution, such as the drainage that originates in the surrounding urban areas.

The highest mortality rate was observed at S1, where the Iguaçu River is formed. This finding means that the water quality of the tributaries is highly compromised. Thus, the sampled areas did not reflect a contamination gradient, a factor which is reflected in the high mortality rate of embryo-larval at all 5 sites. This mortality rate also indicates that the water quality does not meet the parameters required for environmental and human health safety.

The Iguaçu River is extremely important, particularly because the subbasin of the river (the area under study) includes most of the water supply sources in use by the human populations in the region. This is therefore a very critical situation, and urgent urban planning and environmental recovery measures are needed to prioritize the watersheds used for the local water supply.

Densely populated areas and the large cities that they surround have a variety of impacts on water quality. This impact is reflected in the irreversible effects on local rivers, which include the extinction of local species and high degrees of contamination that prevent the water's use for human supply. The disappearance of species recorded in the main channel of the river presents only a small part of the problem; the main warning signs are the loss of biodiversity and limitations to the services that the water source can provide, since the headwaters of the Iguaçu River are a strategic hotspot for the drinking water supply used by the greater Curitiba area.

\section{Acknowledgements}

We would like to thank Geographer Tereza Hoffmann for the help with the location map of the study area. We would also like to thank the Brazilian agency known as the Coordination for the Improvement of Higher Education Personnel (CAPES) for the financial support.

\section{References}

Abilhoa, V., Boscardin, C.R., 2004. A ictiofauna do alto curso do Rio Iguaçu na Região Metropolitana de Curitiba, Paraná: perspectivas para sua conservação. Sanare Revista Técnica da Sanepar 22, 58-65.

Adema-Hannes, R., Shenker, J., 2008. Acute lethal and teratogenic effects of tributyltin chloride and copper chloride on mahi mahi (Coryphaena hippurus) eggs and larvae. Environ. Toxicol. Chem. 27, 2131-2135. https://doi.org/10.1897/07369.1.

Andreatta, E.R., 1979. Influência de Diferentes Dosagens e Intervalos entre Aplicações de Gonadotrópicas Coriônica Humana (HCG) sobre a Reprodução do Jundiá Rhamdia sapo (Valenciennes, 1840). 51f. Dissertação (Mestrado de
Zootecnia) - Curso de Pós-graduação em Zootecnia, Universidade Federal de Santa Maria, Santa Maria. Unpublished results.

American Society for Testing and Materials (ASTM), 1993. Standard guide for conducting acute toxicity tests with fishes, macroinvertebrates and Amphibians, E 729-88a, pp 360-369. Annu. Book ASTM (Am. Soc. Test. Mater.) Stand. 11, $456-475$.

Agency for Toxic Substances and Disease Registry (ATSDR), 1995. Toxicological Profile for Polycyclic Aromatic Hydrocarbons (PAHs). U.S. Department of Health and Human Services, Public Health Service, Atlanta, GA.

Baird, C., Cann, M., 2008. Environmental Chemistry, fourth ed. W H Freeman Co., New York.

Baumgartner, G., Pavanelli, C.S., Baumgartner, D., Bifi, A.G., Debona, T., Frana, V.A., 2012. Peixes Do Baixo Rio Iguaçu, Primeira Ed. Eduem, Maringá, Paraná, p. 203. https://doi.org/10.7476/9788576285861.

Beketov, M.A., Liess, M., 2012. Ecotoxicology and macroecology - time for integration. Environ. Pollut. 162, 247-254.

Blanchard, M., Teil, M.J., Ollivon, D., Legenti, L., Chevreuil, M., 2004. Polycyclic aromatic hydrocarbons and polychlorinated biphenyls in wastewaters and sewage sludges from the Paris area (France). Environ. Res. 95, 184-197.

Brazil, 2005. Brazilian National Environment Council (CONAMA). Url. Resolution $\mathbf{n}^{\circ}$ 357/2005. http://www.mma.gov.br/port/conama/res/res05/res35705.pdf. (Accessed 5 May 2015).

Breivik, K., Sweetman, A., Pacyna, J.M., Jones, K.C., 2002. Towards a global historical emission inventory for selected PCB congeners - a mass balance approach: 1. Global production and consumption, Sci. Total Environ 290, 181-198.

Brito, I.A., López-Barrera, E.A., Araújo, S.B.L., Oliveira Ribeiro, C.A., 2017. Modeling the exposure risk of the silver catfish Rhamdia quelen (Teleostei, Heptapteridae) to wastewater. J. Ecol. Model 347, 40-49.

Carls, M.G., Rice, S.D., 1988. Sensitivity differences between eggs and larvae of walleye pollock (Theragra chalcogramma) to hydrocarbons. Mar. Environ. Res. 26, 285-297.

Coordination of the Metropolitan Region of Curitiba (COMEC), 1999. Zoneamento Ecológico-Econômico Proposto para a Área de Proteção Ambiental do Iraí (Curitiba PR, Brazil).

Debruyn, A.M.H., Wernick, B.G., Stefura, C., McDonald, B.G., Rudolph, B.L., Patterson, L., Chapman, P.M., 2007. In situ experimental assessment of lake whitefish development following a freshwater oil spill. Environ. Sci. Technol. 41, 6983-6989.

DIN 38415-38416 DIN, 2001. Suborganismische Testverfahren (Gruppe T) Teil 6: Giftigkeit Gegenüber Fischen Bestimmung der nicht akut giftigen Wirkung von Abwasser auf die Entwicklung von Fischeiern über Verdünnungsstufen (T 6). [German standard methods for the examination of water, wastewater and sludge-Subanimal testing (group T)-Part 6: Toxicity to fish. Determination of the non-acute-poisonous effect of wastewater to fish eggs by dilution limits (T6)]. Beuth Verlag, Berlin, Germany.

Embry, M.R., Belanger, S.E., Braunbeck, T.A., Galay-Burgos, M., HaLoDer, M., Hinton, D.E., Léonard, M.A., Lillicrap, A., Norberg-King, T., Whale, G., 2010. The fish embryo toxicity test as an animal alternative method in hazard and risk assessment and scientific research. Aquat. Toxicol 97, 79-87.

Ferreira, A.A., Oliveira Nuñer, A.P., Esquivel, J.R., 2001. Influência do ph sobre ovos e larvas de jundiá, Rhamdia quelen (Osteichthyes, Siluriformes). Acta Sci. 23, $477-481$.

Forbes, V., Richard, M.S., Peter, C., 2001. Toxicant impacts on density-limited populations: a critical review of theory, practice, and results. Ecol. Appl. 11, 1249-1257.

Franco, P.L.P., 2010. Análise da Potencialidade do Reúso Indireto Potável: estudo de Caso da ETE Atuba Sul. Região Metropolitana de Curitiba, p. 238. Unpublished results.

Gallotta, F.D., Christensen, J.H.J., 2012. Source identification of petroleum hydrocarbons in soil and sediments from Iguaçu River Watershed, Paraná, Brazil using the CHEMSIC method (CHEMometric analysis of Selected Ion Chromatograms). Journal of Chromatography 27, 1235-149-58.

Grimm, V., 1999. Ten years of individual-based modelling in ecology: what have we learned and what could we learn in the future? Ecol. Model. 115, 129-148.

Gubiani, E.A., Gomes, L.C., Agostinho, A.A., 2012. Estimates of Population Parameters and Consumption/biomass Ratio for Fishes in Reservoirs, vol. 10. Ichthyol, Paraná State, Brazil. Neotrop, pp. 177-188.

Guo, W., He, M.C., Yang, Z.F., Lin, C.Y., Quan, X.C., Men, B., 2009. Distribution, partitioning and sources of polycyclic aromatic hydrocarbons in Daliao River water system in dry season, China. J. Hazard Mater. 164, 1379-1385.

Hamada, N., 2008. Ensaios de Toxicidade Empregados na Avaliação de Efeitos no Sistema de Tratamento de Esgotos e Efluentes. In: e seu Entorno, Utilizando Organismos Aquáticos. ETE Suzano, São Paulo, p. 75. Unpublished results).

Environmental Institute of Paraná (IAP), 2009. Monitoramento da Qualidade dos Rios da Bacia do Alto Iguaçu, na Região Metropolitana de Curitiba, no Período de 2005 a 2009/Instituto Ambiental do Paraná. IAP, Curitiba, 2009. Elenize M. de Fernandes, Leda Neiva Dias, Ana Márcia A. Nieweglowski, Ana Carolina Wosiack. Editora Fundamento.

Brazilian Institute of Geography and Statistics (IBGE), 2008. Indicadores de Desenvolvimento Sustentável: Brasil 2008. Coordenação de Recursos Naturais e Estudos Ambientais [e] Coordenação de Geografia, 2008. IBGE, Rio de Janeiro, p. 472. Estudos e pesquisas. Informação geográfica, ISBN 978-85-240-3947-8.

Brazilian Institute of Geography and Statistics (IBGE), 2010. Indicadores de Desenvolvimento Sustentável: Brasil 2010. Coordenação de Recursos Naturais e Estudos Ambientais [e] Coordenação de Geografia. IBGE, Rio de Janeiro, p. 443. 
Estudos e pesquisas. Informação geográfica, ISBN 978-85-240-4133-4.

Brazilian Institute of Geography and Statistics (IBGE), 2012. Censo Demográfico. Url, Brasil. Rio de Janeiro accessed 12.03.15. www.ibge.gov.br/Censos/Censo_ Demografico_2010.

Katsumiti, A.K.F., França, P.P., Zandoná, E.M., Benicá, C., Silva de Assis, H.C., Cestari, M.M., Marchio, J., Randi, M.A.F., Roche, H., Oliveira Ribeiro, C.A., 2013. Evaluation five years after a refinary oil spill in freshwater wetland - paraná state, southern of Brazil. Ecotoxicol Environ Cont 8, 77-87.

Kendall, R.J., et al., 2001. Ecotoxicology. In: C.D (Ed.), Casarett and Doull's Toxicology: the Basic Science of Poisons Klaassen. McGraw-Hill, New York, pp. 1013-1045.

Knie, J.L.W., Lopes, W.B., 2004. Testes Ecotoxicológicos: Métodos, Técnicas e Aplicações. FATMA/GTZ, Florianópolis, p. 289.

Lande, R., 1993. Risks of population extinction from demographic and environmental stochasticity and random catastrophes. Am. Nat. 142, 911-927.

Leite, N.F., Peralta-Zamora, P., Grassi, M.T., 2011. Distribution and origin of polycyclic aromatic hydrocarbons in surface sediments from an urban river basin at the Metropolitan Region of Curitiba, Brazil. J Environ Sci 23, 904-911.

Lied, E.B., Rodrigues, M.L., 2011. Tratabilidade de Águas Residuárias de Indústria de Carnes em Termos de Toxicidade Aguda com Daphnia Magna. II Congresso Brasileiro de Gestão Ambiental.

Machado, K.S., Cardoso, F.D., Azevedo, J.C.R.A., Braga, C.B., 2014a. Occurrence of female sexual hormones in the Iguazu river basin, Curitiba, Paraná State, Brazil. Acta Sci. Technology Maringá 36, 421-427.

Machado, K.S., Figueira, R.C., Côcco, L.C., Froehner, S., Fernandes, C.V., Ferreira, P.A., 2014b. Sedimentary record of PAHs in the Barigui River and its relation to the socioeconomic development of Curitiba, Brazil. Sci. Total Environ. 482-483, 42-52.

MacPhail, R.C., Brooks, J., Hunter, D.L., Padnos, B., Irons, T.D., Padilla, S., 2009. Locomotion in larval zebrafish: influence of time of day, lighting and ethanol. Neurotoxicology 30, 52-58.

Mater, L., Alexandre, M.R., Hansel, F.A., Madureira, L.A.S., 2004. Assessment of lipid compounds and phosphorus in mangrove sediments of santa catarina island, SC, Brazil. J. Braz. Chem. Soc. 15, 725-734.

Mckean, W., 1980. Pulp and paper industry. In: Guthrie, F.E., Preey, J.J. (Eds.), Introduction to Environmental Toxicology. Elsevier, North Holland.

Millennium Ecosystem Assessment, 2005. Ecosystems and Human Well-being: Wetlands and Water Synthesis. World Resources Institute, Washington, DC.

Neff, J.M., 1979. Polycyclic Aromatic Hydrocarbons in the Aquatic Environment: Sources, Fate and Biological Effects. Applied Science Publishers, Ltd., Essex, England.

Nieto, R., 2000. Caracterização Ecotoxicológica de Efluentes Líquidos Industriais ferramenta para Ações de Controle da Poluição das Águas. In: XXVII Congresso Interamericano de Engenharia Sanitária e Ambiental, Porto Alegre. Unpublished results.

Pegorini, E.S., Andreoli, C.V., Souza, M.L.P., Fernandes, F., Doetzer, B., Ferreira, A.C., 2003. Produção e Disposição Final de Lodo de Esgoto na Reciclagem Agrícola da Região Metropolitana de Curitiba - PR. Simpósio sobre biossólidos no âmbito do Mercosul. São Paulo.

Piaia, R., Baldisserotto, B., 2000. Stocking density and growth of Rhamdia quelen (Quoy \& Gaimard, 1824) fingerlings. Ciência Rural. 30, 509-513.

Pimm, S.L., Jones, L., Diamond, J., 1988. On the risk of extinction. Am. Nat. 132, 757-785.

Porto, M.F.A., 2007. Projeto Enquadramento - Bacias Críticas: Bases Técnicas para a Definição de Metas Progressivas para seu Enquadramento e a Integração com os demais Instrumentos de Gestão. Relatório Parcial n¹2. Fundação Centro Tecnológico de Hidráulica - UFPR. Cooperação SUDERHSA. Curitiba.

Powers, C.M., Slotkin, T.A., Seidler, F.J., Badireddy, A.R., Padilla, S., 2011. Silver nanoparticles alter zebrafish development and larval behavior: distinct roles for particle size, coating and composition. Neurotoxicol. Teratol. 33, 708-714.
Prochazka, E., 2009. Incidence of Malformations in Fish Embryos/larvae (Review). Smart Water Research Facility, Griffith University - Nathan/Gold Coast Campus.

Renshaw, E., 1991. Modelling Biological Populations in Space and Time. Cambridge University Press.

Rodrigues-Galdino, A.M., Maiolino, C.V., Forgati, M., Donatti, L., Mikos, J.D., Carneiro, P.C., Rios, F.S., 2010. Development of the neotropical catfish Rhamdia quelen (Siluriformes, Heptapteridae) incubated in different temperature regimes. Zygote 18, 131-144.

Department of the Environment and Water Resources of Parana (SEMA), 2010 Bacias Hidrográficas do Paraná - Série Histórica. Organizadores Mauri César Barbosa Pereira e José Luiz Scroccaro. Url, Curitiba, 2010. www.meioambiente. pr.gov.br. Accessed 02.01.18.

Setti, A.A., Lima, J.E.W., Chaves, A.G.M., Pereira, I.C., 2001. Introdução ao Gerenciamento de Recursos Hídricos, 3a ed. Agência Nacional de Energia Elétrica; Agência Nacional de Águas, Brasília.

Shepp, D.L., Cummins, J.D., 1997. Restoration in an urban watershed: anacostia river of Maryland and the District of Columbia. In: Williams, J.E., Wood, C.A., Dombeck, M.P. (Eds.), Watershed Restoration: Principles and Practices. Am. Fish. Soc. Bethesda, Maryland, pp. 297-317.

Soclo, H.H., Garrigues, P., EwaLoD, M., 2000. Origin of polycyclic aromatic hydrocarbons (PAHs) in coastal marine sediments: case studies in Cotonou (Benin) and Aquitaine (France) areas. Mar. Pollut. Bull. 40, 387-396.

Water Resources Development and Environmental Sanitation SUDERHSA, 1997 Qualidade das Águas Interiores do Estado do Paraná, pp. 1987-1995 (Curitiba PR, Brazil).

Tabachnic, B.G., Fidell, L.S., 1996. Using Multivariate Sstatistics. Harper Collins College Publishers, New York.

Tundisi, J.G., 2011. Água No Século XXI: Enfrentando a Escassez, Terceira Ed, Rima/ IIE, São Carlos, Brasil, p. 256.

Uchmanski, J., 1999. What promotes persistence of a single population: an individual-based model. Ecol. Model. 115, 227-241.

United Nations Educational, Scientific and Cultural Organization - UNESCO, 2015. Relatório Mundial das Nações Unidas sobre Desenvolvimento dos Recursos Hídricos. Água para um Mundo Sustentável, p. 8.

United States Environmental Protection Agency (US EPA), 2007. Method 6010C Inductively Coupled Plasma - Atomic Emission Spectrometry, p. 72. Feb. 2007, rev.03. www.epa.gov/epaoswer/hazwaste/test/pdfs/6010c.pdf. Accessed 11.05.15.

Vitule, J.R.S., Abilhoa, V., 2009. Plano de Conservação para Espécies da Ictiofauna Ameaçada no Paraná, in: Plano de Conservação para Peixes de Água Doce da Planície Litorânea do Paraná. Instituto Ambiental do Paraná, Paraná, pp. 13-25.

Wade, T.L., Cantillo, A.Y., 1994. Use of standards and reference materials in the measurement of chlorinated hydrocarbon residues. Chemistry Workbook NOAA Technical Memorandum NOS ORCA 77, 59.

Von Westernhagen, H., Hoar, W.S., Randall, D.J., 1988. Sublethal Effects of Pollutants on Fish Eggs and Larvae. Fish Physiology. Academic Press, pp. 253-346.

World Health Organization (WHO), 1998. Selected Nonheterocyclic Polycyclic Aromatic Hydrocarbons, Environmental Health Criteria 202. United Nations Environment Programme. International Labour Organization, Geneva. Url. http:// www.inchem.org/documents/ehc/ehc/ehc202.htm. (Accessed 22 July 2015).

Yao, M., Li, Z., Zhang, X., Lei, L., 2014. Polychlorinated biphenyls in the centralized wastewater treatment plant in a chemical industry zone: source, distribution, and removal. J. Chem. https://doi.org/10.1155/2014/352675.

Zawadzki, C.H., Renesto, E., Bini, L.M., 1999. Genetic and morphometric analysis of three species of the genus Hypostomus Lacépède, 1803 (Osteichthyes: loricariidae) from the Rio Iguaçu basin (Brazil). Revue Suisse de Zoologie, Genève 106 (1), 91-105.

Zhang, Z., Huang, J., Yu, G., Hong, H., 2004. Occurrence of PAHs, PCBs and organochlorine pesticides in the tonghui river of beijing, China. Environ. Pollut 130, 249-261. 